\title{
Arte indígena en Costa Rica
}

Fue hacia el año 1997 cuando la intuición de historiadora me llevó a observar detenidamente a mi alrededor, mientras mi cuerpo brincoteaba sobre la curtida cuerina verduzca del pintoresco bus, siendo aún apacible el recorrido de la ruta desde la provincia de Limón hasta el minúsculo pueblo de Puerto Viejo de Talamanca. El bamboleo del cacharro, sobre la rústica carretera, hacía cruzar mi atención desde las peculiaridades fisonómicas y particularidades sociales de los otros pasajeros hasta el intento por permanecer en la contemplación embobada del oblicuo litoral atlántico e imaginar sumergirme en esas olas que bailan calipsos entre la espuma y el brillo del sol, que no cesa de brincar y saltar sobre la superficie del mar, el cual, paralelamente, nos acompañaba. Mas fueron la musicalidad y acentos ingleses e isleños de Radio Casino, unidos a esos chillantes colores engalanando la lata del entonces destartalado bus a Sixaola, los cuales primero me hablaron de la riqueza cultural que borbotonea en esta zona del país, antigua testigo y partícipe del cónclave Caribe y su particular historia, el origen de nuestra historia.

De banca en banca se fue acercando la señora indígena kuna, hasta que se sentó junto a mí. Sorprendida sonreí, pero dejé caer mi mandíbula cuando, no sé de cuál escondrijo entre su blusón, decididamente sacaba y me mostraba bolsos, vestimentas y adornos, elaborados totalmente a mano con la técnica de la "mola", esas bellas muestras artesanales de su singular cultura, todas trabajadas con un excelente acabado y buen gusto en la escogencia de la combinación de colores. Me observó observando, posiblemente en un seguimiento inconsciente, según ancestral costumbre de vigilar en sigilo, pero también con la vena del

Carolina

Jiménez. Historiadora de arte, artista plástica y máster en Tecnología Educativa. Realiza trabajo independiente en investigación de campo y recopilación de elementos autóctonos de la región de la Alta y Baja Talamanca donde reside de manera permanente desde hace unos 15 años. carolinajimenez@racsa.co.cr intercambio y el comercio en los genes; y es por lo que se me acerca con obvia intención de hacer una venta, mientras hablaba y hablaba sin que yo le pudiera comprender. En adelante, faltaron pocos años para que este encuentro, que generó mi motivación por vender artesanías a turistas, pasara a ser un proyecto de investigación, documentación y apoyo al artesano indígena de esta gran familia originaria de la que descendemos de este lado del país, la Macrochibcha.

Los primeros artesanos indígenas en visitar el espacio donde vendería artículos de recuerdo, al final del mismo año, fueron dos hermanos, panameños también, Ronaldo e Isaías Gamarra, hijos de la legendaria maestra artesana Celedonia Hernández Santana, descendiente de la familia Santana — apellido del actual linaje 
real- $y$ todos ellos del pueblo Plûyo Naso Teribe, conocidos antiguamente como los Tiribíes. Muy pronto se corrió la voz sobre la persona comprando artesanía, y ha sido un privilegio poder conocer personalmente a muchos otros artesanos que se acercaron a mostrar sus productos o visité, luego ya, y sobre todo, en nuestro territorio, de los pueblos Cabécar y Bribri. Ese encuentro resultó crucial en ese momento, pues, desde el punto de vista del artesano indígena, se sufría de años de caida del mercado artesanal a nivel regional y nacional, debido a los cambios clusión en el comercio de diferentes materiales industrializados, como el plástico.

Productos de gran calidad en su manufactura y con un alto sentido utilitario que sencillamente dejaron de utilizarse en los hogares costarricenses son: el me cate natural, el hilo de pita, las hamacas de hilo natural o los muchos recipientes realizados a partir del cascarón del guacal o jicara, recordemos por ejemplo el ros con tapa infaltables en el hogar por su belleza y estilo rogion costureros con tapa, infaltables en el hogar por su belleza y estilo regionalizado; y no ovidemos los canastos para la ropa, hechos con bejucos o con fibra de palmas huevos o la can astita para servir pan o tortillas, todos antiguamente de am los uso popular.

A pesar de esa pérdida de mercado, la gran mayoría de los pobladores de los territorios indígenas en Costa Rica mantienen la tradición en el trabajo artesatanto por la falta de estrategias de comercialización como por la carencio del tanto písico donde se acostumbraba realizar las actividades de comercio y que de productos, el fantástico mercado, esa importantísima y popular plazaque de produ de oficio se respeta.

La intención por colaborar en revivir y mantener palpitante la tradición artístiLa intencio co-artesanal en familias Cábecar y Bribri, de la Región Atlántica, por buscar que cada vez más familias retomen esa escuela, surge de admirar su sistema de vida que basa la economía doméstica y de ingreso familiar en el cultivo de la finca y la complementa con la venta del trabajo artesanal, realizado en familia, tal y como trueque o para el uso doméstico, como en los viejos tiempos.

Con el paso de los años, la iniciativa y el interés en el tema creció. Se popularizó y se ha diversificado en varias direcciones y desde ángulos diferentes; hasta el punto en que cada vez más la artesanía y el arte indígena costarricense son no solo mejor reconocidos, respetados y promovidos comercialmente, sino que incluso muchos de estos objetos, realizados y coloreados solamente con elementos na muchos de estos objetos, realizados y coloreados solamente con elementos naimportantes centros culturales e incluso en museos del siempre etnocéntrico vall importantes centros culturales e incluso en museos del siempre etnocentrico valle la artesanía indígena mantiene un componente conceptual tradicional subyacente en los objetos elaborados, y el artesano maneja tal excelencia en su trabajo que merece ser destacado como persona artista sobresaliente en su campo.

El análisis detallado del fidedigno dibujo naturalista y el observar la agradable estilización anatómica en el tratamiento de las figuras, así como mi asombro conocer sobre los temas utilizados en el decorado de los guacales tallados por el artesano bribri Armando Rodríguez Sancho, de Uatsi de Talamanca, han sido el inicio del proceso de visualización e identificación de esta riqueza cultural narrada con linea suave y maestra, pero además, colmada de historia y cosmovision. Entonces, esos sencillos "recuerdos para el amigo turista" pasade tallarse para narrar mi cultura".

Los guacales-cantimplora tienen un cordon natural hecho a mano para colgarlos del hombro, pues, antiguamen-

tes productos que menos utilidad pre-

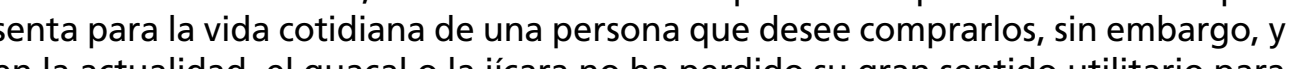

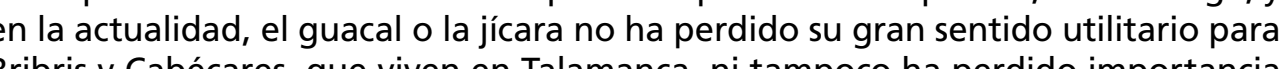

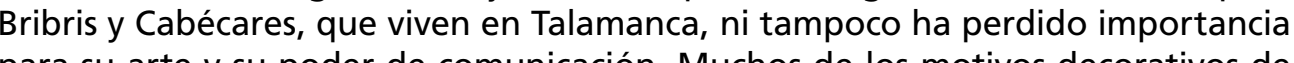
pas a cos cos los guacales y jicaras, no solo de Armando, sino vién mo ya como un comun denominador en talladores indigenas de otros territorios y pueblos originarios de Costa cula paramientar el artístico sentido de la estilización, el buen manejo de la propor ción volumetrí y conocimiento an tómico de los personajes dibujados, el sentido nato de la ubicacín espaciali sobre todo, tomando en cuenta que se trabaja sin patrón, se talla la idea directamente sobre el guacal o jícara, que se trabaja sin patron, se talla la idea directamentabre sobre el guacal o jicara, o madera, y es

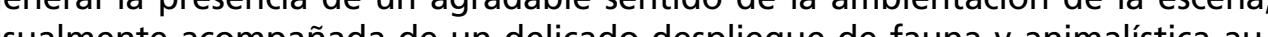
tóctonas, lo que lo definen.

Observar, haciendo este tipo de análisis, demuestra por qué el trabajo en dibujo y escultura de nuestros artistas indígenas, reúne una serie de cualidades y flora lo exales y del manejo de las formas y el volumen que definitivamente lo y flora locales y del manejo de las fontas y el volumen, que definitivamente lo que su trabajo posee estos atributos de forma, una acertada interpretación acerque su trabajo posee estos atributos de forma, una acertada interpretación acerdefinir de qué manera un artesano especializado interpreta y mantiene latente con sus dibujos la historia del origen y las costumbres de su pueblo, fiel al papel que en la cosmovisión bribri realizó Sula', padre de Iriria, la niña tierra, y ayudanque en la cosmovision bribri realizo Sula, padre de Iriria, la niña tierra, y ayudante de Dios en la creación, formador de los seres humanos con aguas de colores. aunque es enfático en aclarar que él puede dibujar la historia, mas solamente los awapà, o señores médicos, pueden usar el verbo para narrarla. Los artesanos son artistas innatos y pueden dibujar conceptos culturales y na-
rraciones históricas, pero son años de linaje, largo aprendizaje, estudio y duro en-
Foto 1 Maracas de Armando Rodriguez. Costumbre de la caza trasabe por designio de Dios, cales

caza en la selva. 
trenamiento lo que permite a los usékölpa, o señores médicos aborígenes, utilizar la narración de la historia de su origen en oraciones, para así poder identificars con el mundo espiritual y junto con la medicina tradicional y otros elementos, curar enfermedades. En la arquitectura tradicional Cabecar y Bribri, el ejemplo de este enunciado de materialización de conceptos se da en el rancho cónico tradicional, con todos sus significados historico-culturales. El arte y el concepto han la ima don vidos, tal vez, pero están, y la relacion que síve de puente para crear siempen pisual del mundo conceptual siempre, perdura desde centenios.

Una escultura en miniatura, con forma de tortuga o cocodrilo estilizado, con su lomo y centro abdominal achatados, tallada en madera de balsa por el bribri Rogelio Lopez Morales, o en madera de laurel, por Dimas Diaz Mayorga, de CorbiOsenos o señores principales-, resulta ser una
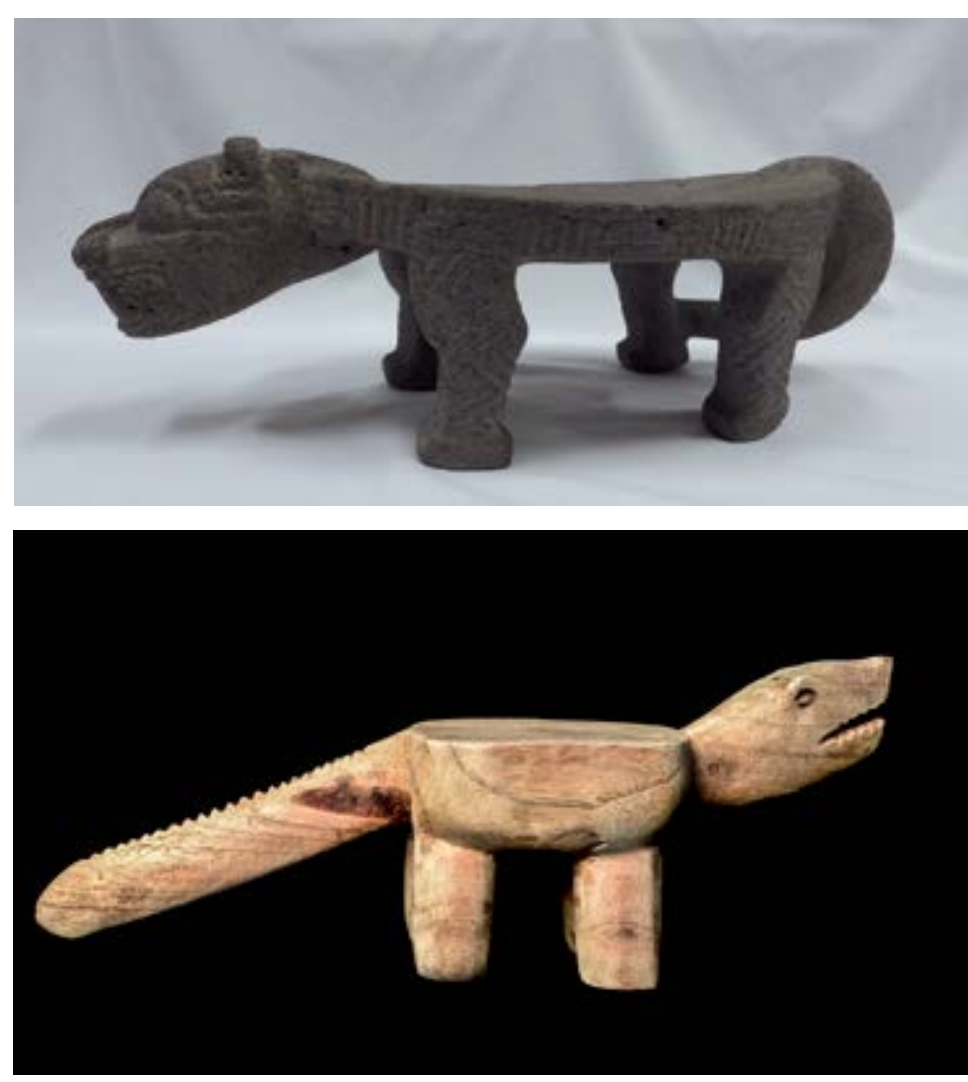
do prapara para uso asiento sagraseñores sukias actuales. Ahora bien, muy interesante, sobre todo para ,llos mismos, notar cómo, a través del tiempo, se siguen manteniendo patrones de trabajo en estilística, recursos de diseño, patrimonio temático, funciodiseño, patrimulización, aunque circunstancias históricas y el materia hayan cambiado. El trabajo de campo ampliado a la Zona Pać́fico Sur, probo que la gran mayoría de los artesanos y artistas actuales no conocen y, por supuesto, no recuerdan, los objetos artísticos realizados por sus antepasados los tiempos de la colonia, ni anteriores, y suelen admirarse cuando observan reconocen por primera vez la iman de un petate en piedra, por ejemplo, o de una talla de algún animal de fauna y constatar de qué manera la herencia estilística se mantiene, aunque el material, línea y decorado sean ahora mucho más sencillos y el momento histórico diferente.

Foto 2. Arriba: una Imagen de felino, talla Atlántica, de la colección del Museo del Oro: y abajo, una talla en

Desde este punto de vista, puedo deducir que los enigmáticos petates de piedra originalmente fueron el asiento del awá, pero trabajados en tiempos de paz y progreso, cuando arte, religión y cultura habían alcando la madurez que
permite la estabilidad política, económica y social, dentro de un sistema de vida exitoso y en pleno desarrollo.

dera de balsa por el bribi

Es posible que parezca inverosímil, pero casi nigún artesano indígena actual sobre todo Cabécar o Bribri de la Región Talamaca Caribe, cuenta con alguna re frencia visual del legado artístico de sus antepasados; en la zona atlántica, esto se debe a que viven en lugares muy alejados y con medios visuales y educativos más limitados que en otras regiones del país, su cotidianeidad pertenece a un sistema diferente $y$, aunque sea difícil creer que no hayan visto antes muestras del legado precolombino, esto es asi porque aún se vive, diariamente, en un entorno natural diferente al de las culdades y su realidad es radicalmente opuesta al sistema capitalista. En ese sentido, se debe tomar en cuenta que, aunque poseen tierra, siembros, vivienda, cultura propia y mucho talento, el dinero escasea. Su arte no se valora ni se requiere como en las ciudades, cierto, péno también se necesita, y la venta de arte y artesanía sigue siendo una opción muy lógica y
viable de complementar en la economía familiar.

De igual manera se nota, en el trabajo con descendientes Bribri, Cabécar, Bruncas, Gnöbe y Térraba de comunidades de la zona Pacífico Sur, el arraigo a técnicas y tradiciones guardadas en el remanente de la memoria, a pesar de que la dinámica del turismo o pseudoayudas al artesano han pretendido convertilos de contenido Sencillamente, desconocemos la importancia cultural del a vas y las artesanias indigenas y no sabemos que hormas ve unánple maraca con una un gran significado ceremonialo muestra una costumbre o una naración histórica.

Existen, por ejemplo, las maracas que presentan un enmarcado de estrella, demos o estilizaciones angulosas que recuerprotección y solamente las suenan canpros, o Tsökölpa, para dictar momenimportantes en las cera dictar montos usa únebre, debe "curarse" internamente con cacao y, en el ritual, cuatro cantores se toman de las manosy el Tsököl principal es quien indica el comienzo del canto, acompañándose con un son muy específico de su maraca exclusiva.

En una interpretación característica, Armando Rodríguez dibuja el momento cuando Sibö, Dios, creó al tigre llamado Namù, o más bien interpreta lamado te en que Dios le da el don de la intelite en que Dios le da el don de la inteligencia, con lineas de puntos sucesivos, estrellado, que representan la fuenza divina y simbolizan protección; las líneas son continuas hasta llegar a la franja central ondulada, la cual es el suave soplo de Dios dando al tigre tanto su pensamiento, como recordatorio de que se lo da para rememorarle la misión que le dio en este
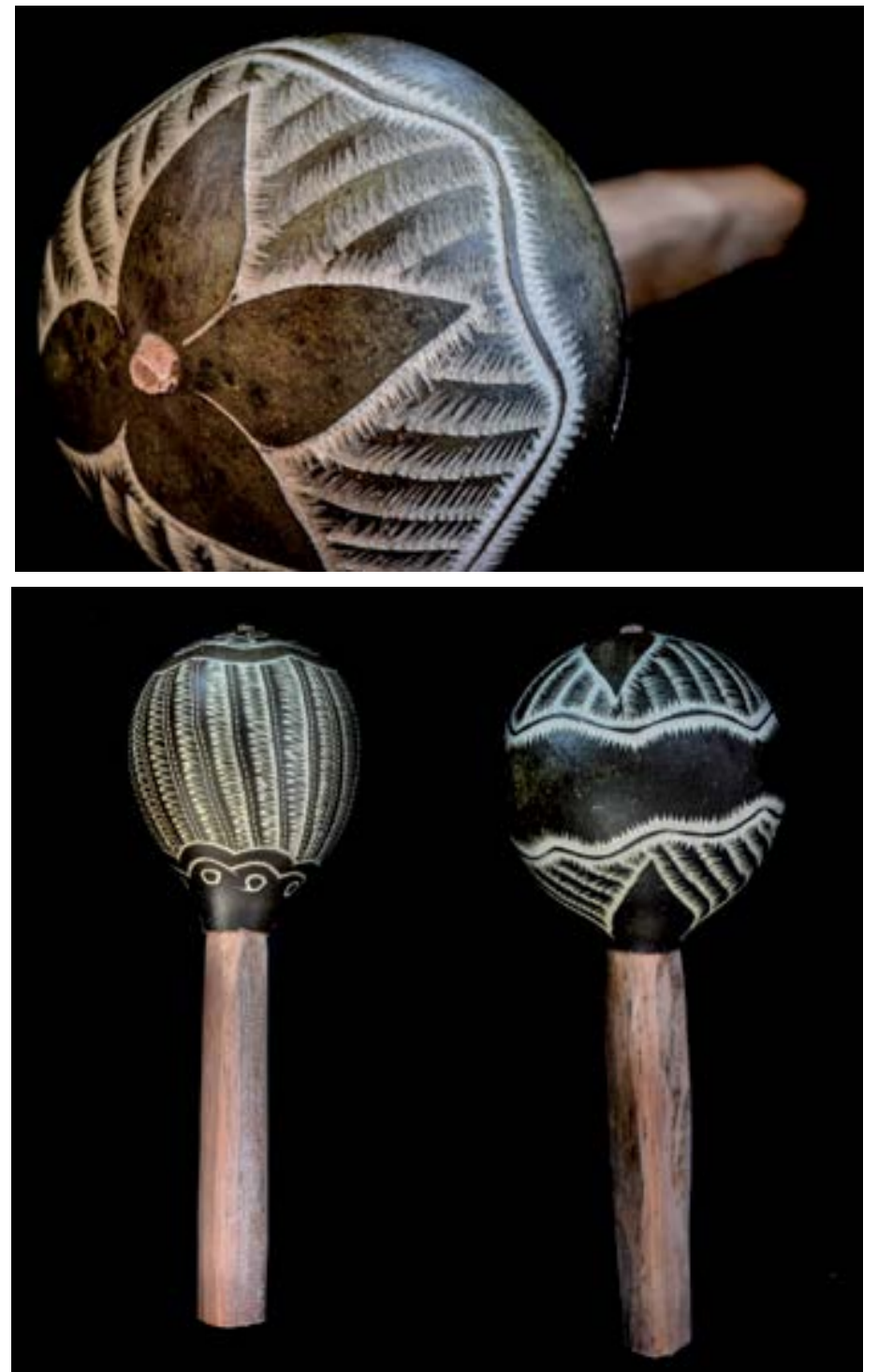
mundo, la cual es defender al indígena. Profundizando un poco más, recuerda que si el hombre blanco o sikua, llega a la selva con malas intenciones, el pode al sortilegio de la luna llena.

Si la maraca está representando a la fémina más temida, la mar, la incisión zigzagueante tallada en filas alargadas y abarcando toda su redondez define diseño que representa el centro del mar, sus movimientos y profundidad. En la mar es una de Bribriwak, u hombre Bribri -como se llaman a sí mismos-, el mar es una mujer, pelgrosa y traicionera, quien, dicho por Armando, "nos traga como a un sorbo de chocolate si nos desculdamos", yesta es la razon por la que de los costados desplegadas en semicirculo y, alrededor, enmarcando la imagen de la mar.

El versátil artesano, Dimas Díaz Mayorga, perteneciente al clan de su madre Wrûkicháwak - dueños del palo de poró donde los primeros médicos dibujaron a los animales, plantas y órganos del cuerpo con los que experimentaron para afianzar los conocimientos y secretos de la medicina-, también puede tallar esculuras y miniaturas de los elementos sagrados del awá, como el asiento y e difer, ilustra el tambor utilizando sus caras opuestas como dos escenarios

Foto 4. Fidelia Rivera Femandez, Xilografía,

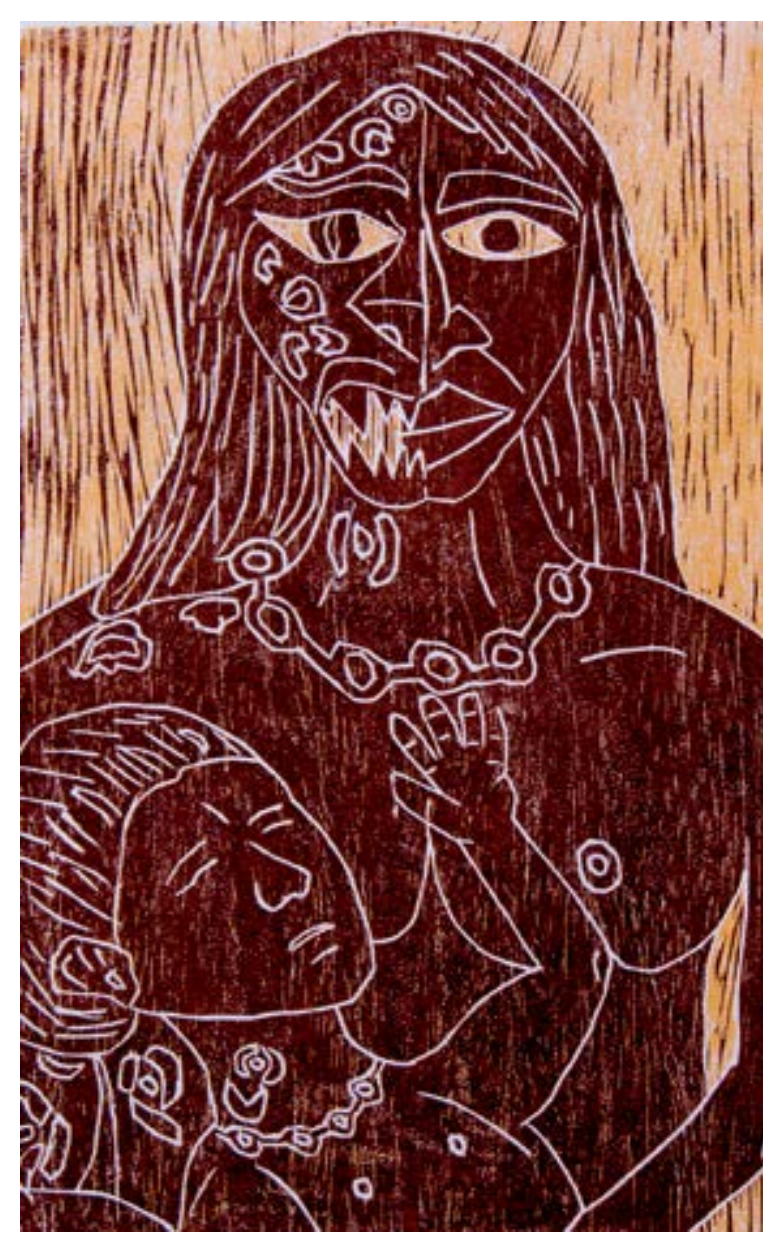

másce sí. Este recurso es muy usado también en máscaras y otras creaciones subjetivas de vivencias trato en su identificación del retrato o autorreyo- para expresar un estado personal con alta carga motiva. En las obras con estas caran alta carel artista trabaja con un dibujo de trazo más fuerte y espontáneo, lo que a veces puede resultar en un estilo expresionista, muy libre y sensible, lleno de fuerza y significado.

Se ha notado, en creaciones recientes de artistas participantes en talleres de enseñanza de otras técnicas respetuosas de la diversidad, una recurrencia en esta búsqueda de patrones y recursos expresivos con arraigo plástico en el simbolismo tradicional. Esto se ejemplariza aquí con la obra de la artista térraba Fidelia Rivera Fernández, quien enseña poder de su alter ego "tigre" en su retrato: ella luchó con cada corte en la madera, logró sentir la catarsis y liberación necesarias para superar una dura experiencia pasada con su hija enferma y asi lo plasma representando esa fuerza natural en una mitad de su rostro y torso.

Esta técnica de expresión dual es frecuente también en quacales-cantimplora, y hasta en maracas, cuando se desea representar a dos sujetos de la narración, el "tigre" y el "sol", sibö y el hombre, Duwàlök y la montaña, Yëria y los animales.

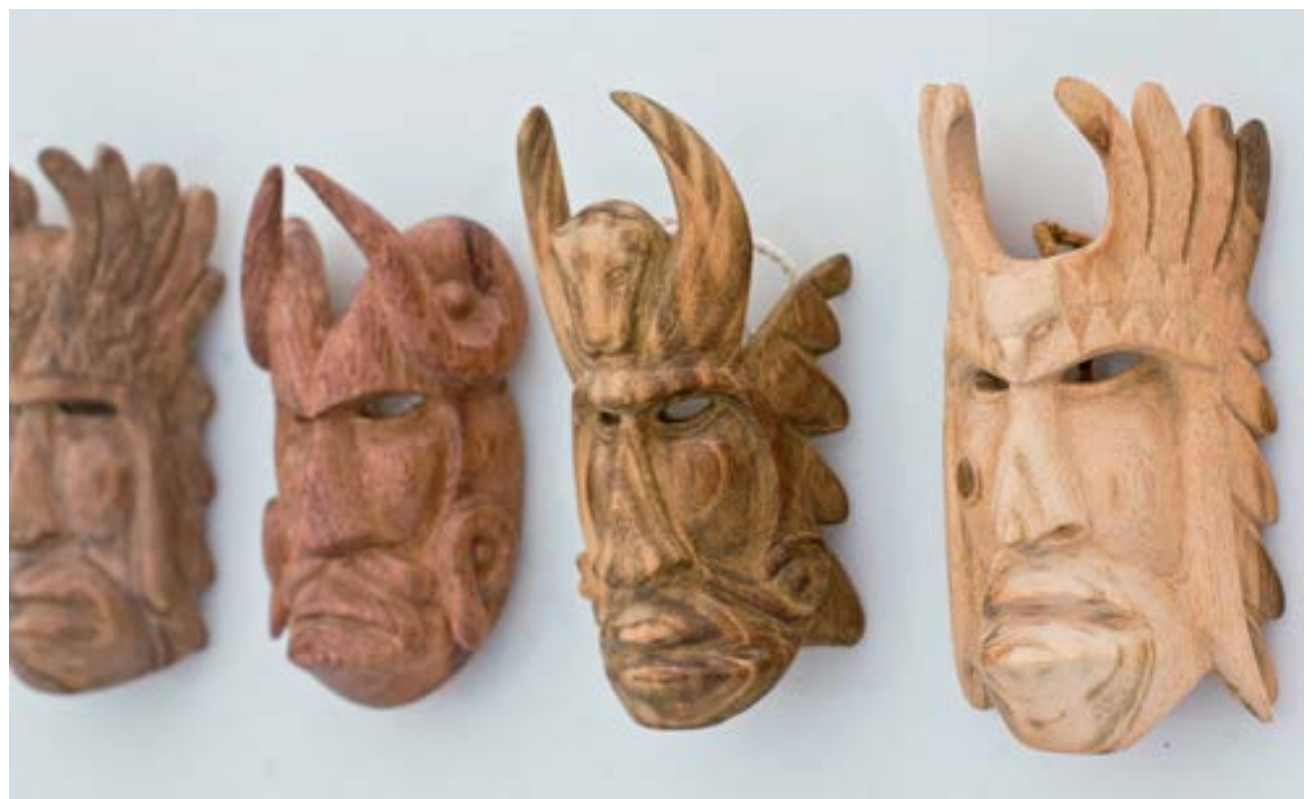

Foto 5. Rafael González

La auténtica máscara brunca se talla respetando la veta de la madera y devela su significado cultural principalmente en el elemento mágico-fantástico que antiguamente acompañó este arte. La máscara no es solo una pretendida forma intimidante contra el enemigo, sino el elemento que, de nuevo, me permite conectarme con mi "otro yo", mi alter ego animal (águila, tigre, serpiente, búho), representado con una estilizada figura tallada coronando la máscara; de hecho es mi "otro yo" el encargado de realizar "la magia" de protección, capaz incluso hasta de manifestarse y materializarse en situación de peligro, para asustar y defender del conquistador o colonizador, léase, amenaza.

Es admirable ver que la familia Cabécar de apellido Navas, Fausto (el padre), Junior y Heinz (los hijos), todos sensibles escultores, aún tallen figuras en madera que interesante porque así constatamos cómo se mantienen fieles las similitudes costumbristas aún hoy, según podemos ver en las personas retratadas en las antiguas fotografías que se encuentran en el libro titulado El espacio y sus hombres, escrito potografias que he encuentran en el libro titulado El espacio y sus hombres, escrito por el notable paños de trab y principalmente, adonde llegó para trabajar a partir de 1873. El libro fue publicado en 1978 y tiene excelentes comentarios del historiador Luis Ferrero.

Igualmente, agrada y sorprende ver cómo, en nuestros días, la talla en madera, inspirada en animales autóctonos de los artistas bribri Walter Estrada Díaz Dimas Mayorga, Johnny Alméngor - o del también bribri, pero del lado del Pacifico Sur, Marvin José Ortiz Figueroa, o del gran especialista brunca Hugo Dennis Fernández González, o el retrato estilizado de las especies pequeñas de la selva en los guacales en miniatura de Rogelio López- aún, con el transcurrir de los años, mantengan de manera impresionante el estilo y la sensibilidad autóctona "puros,", para usar las palabras de la sabia señora bribri Clotilde Mayorga Mayorga, de Corbita; estos trabajos de máxima delicadeza y caracterización esenciales, prueban de qué manera los modelos artísticos siguen manifestándose hereditariamente con su estilo más castizo. 


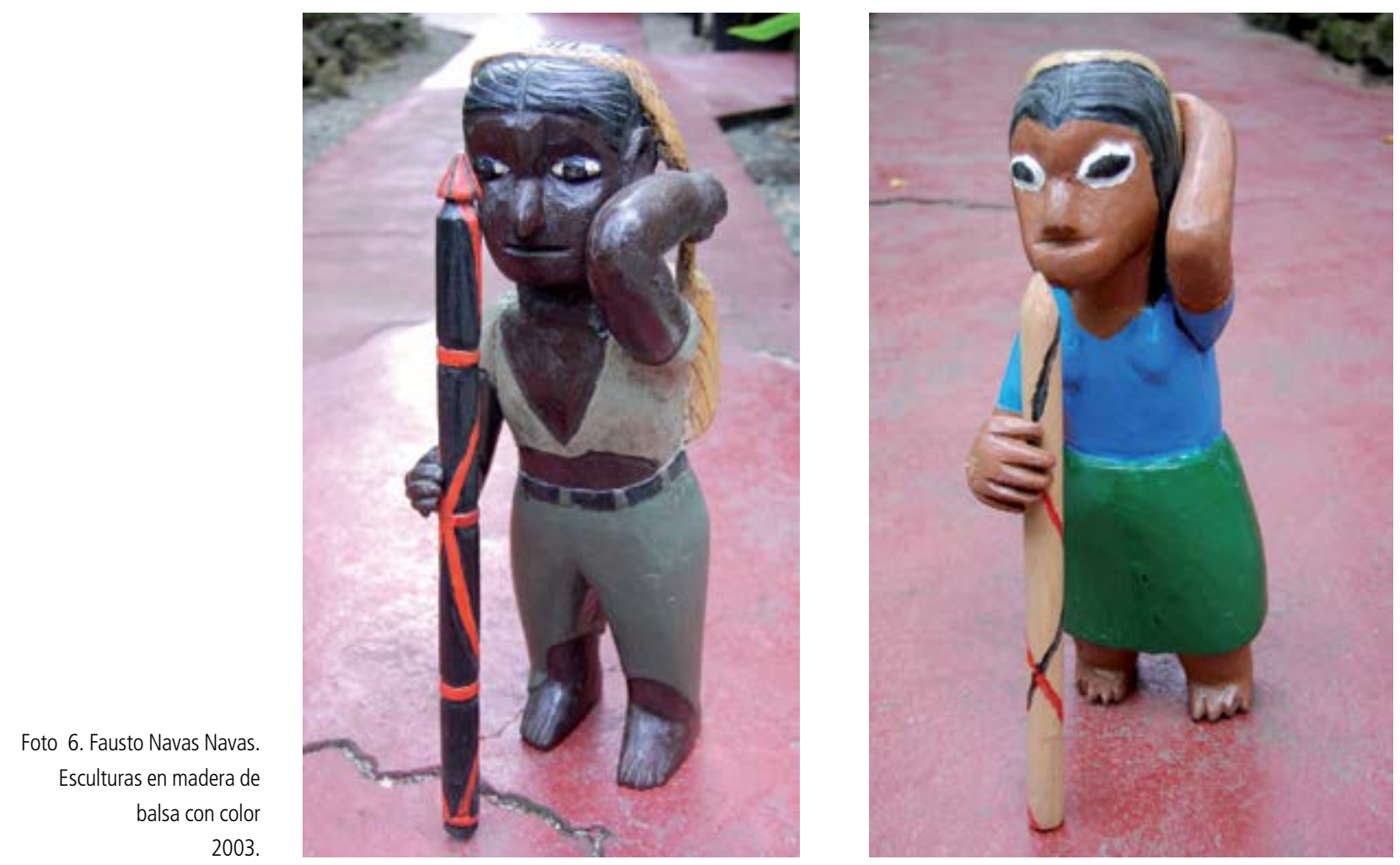

Es grande la riqueza cultural de los objetos sencillos o de uso doméstico, nos pueEs grande la riqueza cultural de los objetos sencillos o de uso doméstico, nos pue-
den recordar la gran alianza que aún podemos obtener sabiamente con el entorno radas con sencillos dibujos de niños, las yuaves curvaturas de la linea nos habode alegres escenas de aves y de un arte animista, donde posiblemente también se muestren las hojas con ojos, y sonrientes, pues son dibujos de niños que crecen con especial empatía con el entorno natul Los abanicos de Pastora Jackson, o co su hija Eraida nos transportan a la costumbre de atizar el fuego - hábito ya olvidado por citadinos, pero aún necesario si se vive en ese otro sistema diferente que Foto 7. Foto de do por se elabora con la hoja del senco, recogida, hervida e hilada como antes. Se decora 1976. con diseños geométricos que corresponden a patrones característicos de su pueblo,

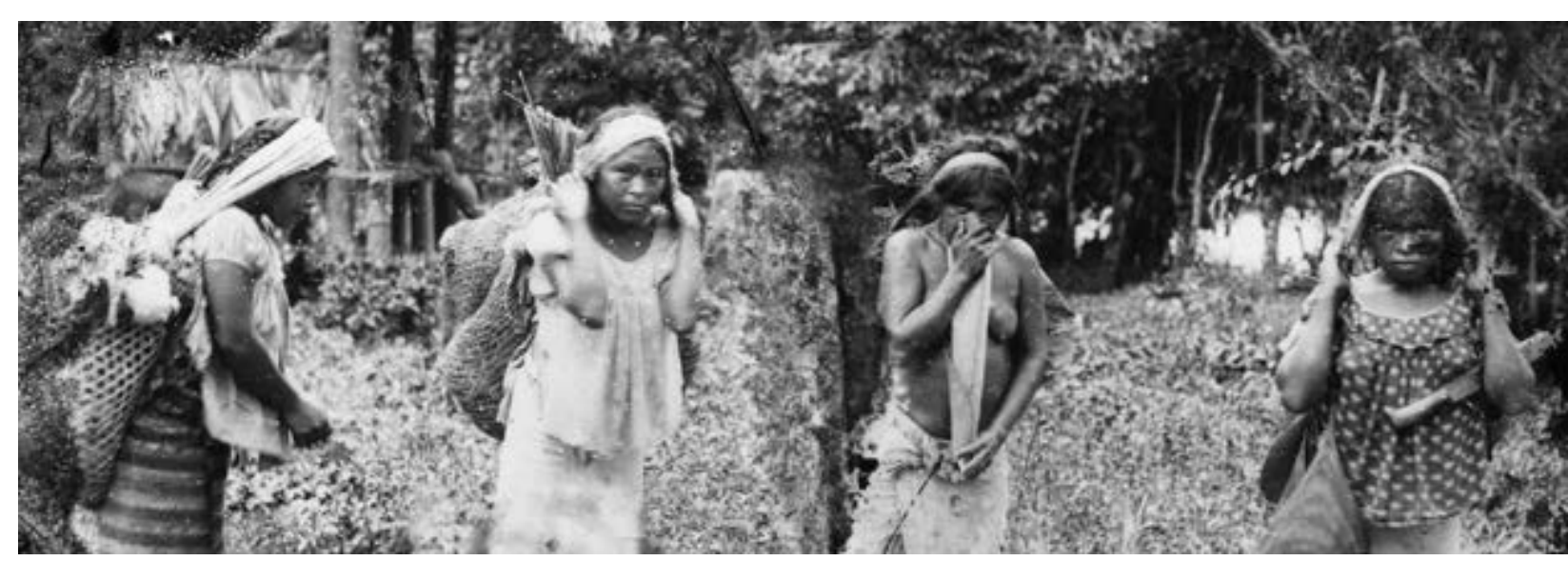

definidos tanto por "la mano de la tejera" como por el color, y el color se jedora" como por el color, y el color se des de la mata azul, que brinda el tono café, o se usa el negro que da el guaitil, cafe, o se usa el negro que da el guaitil, o las variantes del rojo al naranja del Cáro y, por supuesto, el amarilo de la cúrcuma y, asi, en un sencillo canastito, comprobich de la vida y recoge su historia socialy natural.

Y aun en los trabajos más legendarios, como lo son la confección de lanzas y los conjuntos de arco y flechas, realizados por el octogenario don Samuel Lopez Ûtsi o Rancho Grande, se nos hab de tradición pues están hechos de peiibaye y del tallo del verolis, la flor la cañ brava amarrados con mecate elaborado de la hoja de la palma de la pita, con "el pegue" reforzado con la goma del árbol de la caraña, según la

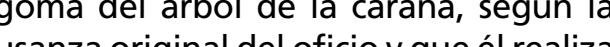
usere pequeño, cuando aprendió de su padre padre. La su machete.

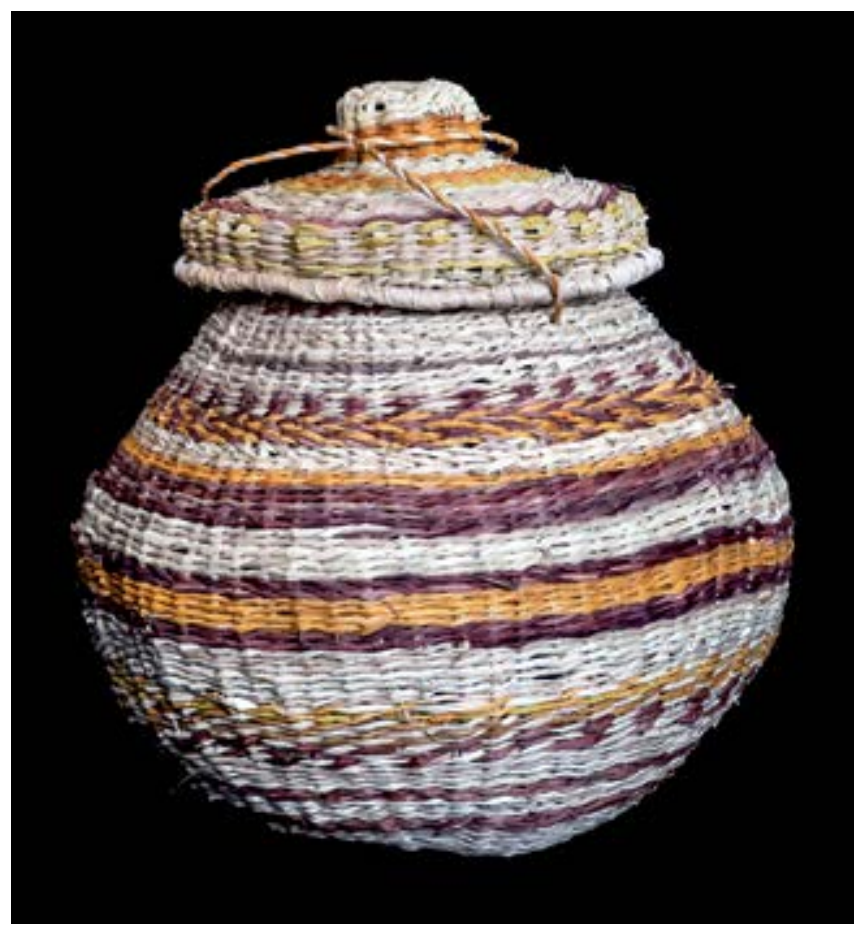

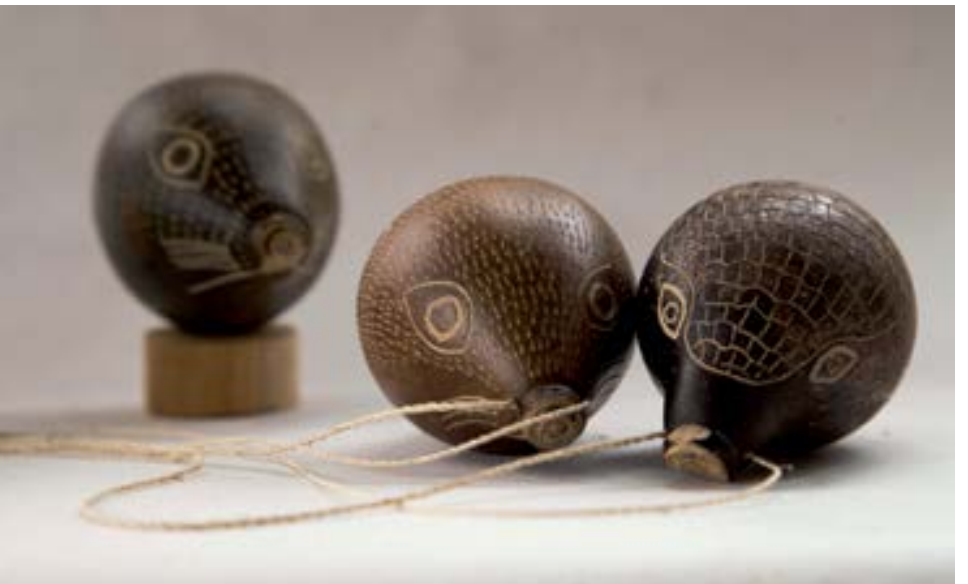

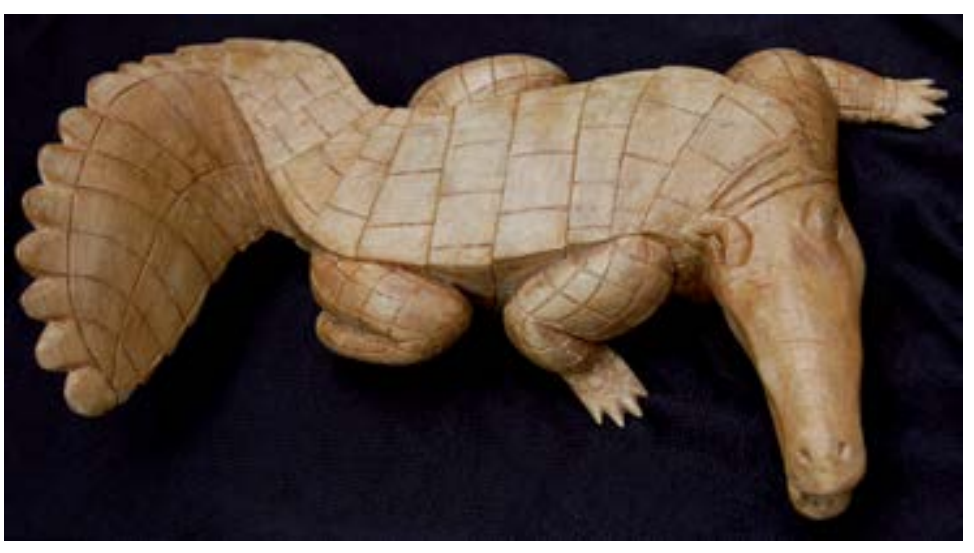

Foto 8. Arriba puerco espin y armadillo de Rogelio Lóp Abaio, figura de cocodilllo, tallada en cedro por Dimas Mayorga.
Foto 9. Teijdos con tintas y fibras naturales elaborados por Claustina Lópers

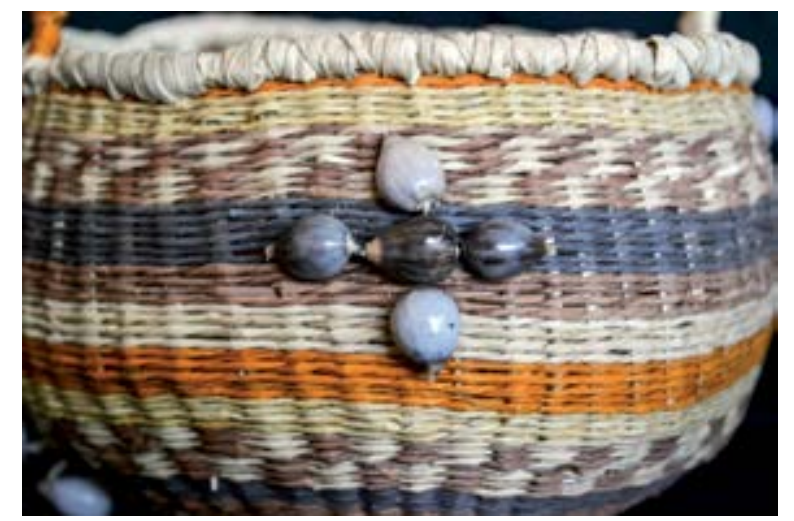



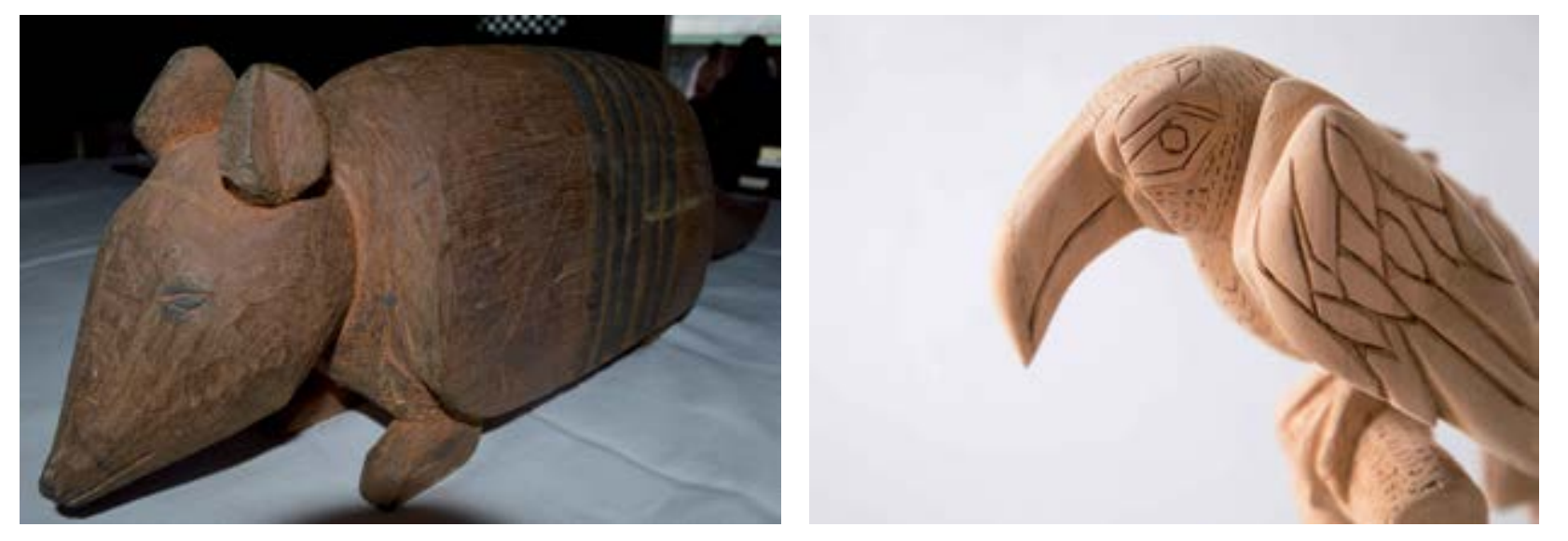

El simple recuerdo de los dibujos preferidos de mi infancia me lleva siempre a evoins a in a Johnny Almengor línea firmemente tallada por la tosca herramienta del artesano indígena. Amengor, a

Ese sentimiento de ternura que acompaña la sutileza de línea en los contornos de las figuras del "indio Sánchez", las delicadas siluetas encontradas en sus dibujos y ficación y pureza de la linea para definir las siluetas de las figurasy la manera como

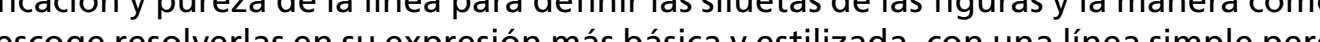
muy expresiva $y$ tan delicada que sus figuras fluyen livianamente entre curvaturo y ondulaciones pareciendo flotar inspiradas por el soplo del viento, en una dialéctica de la dinámica curvilinea, muy caracteristica del dibujo costarricense, que fue

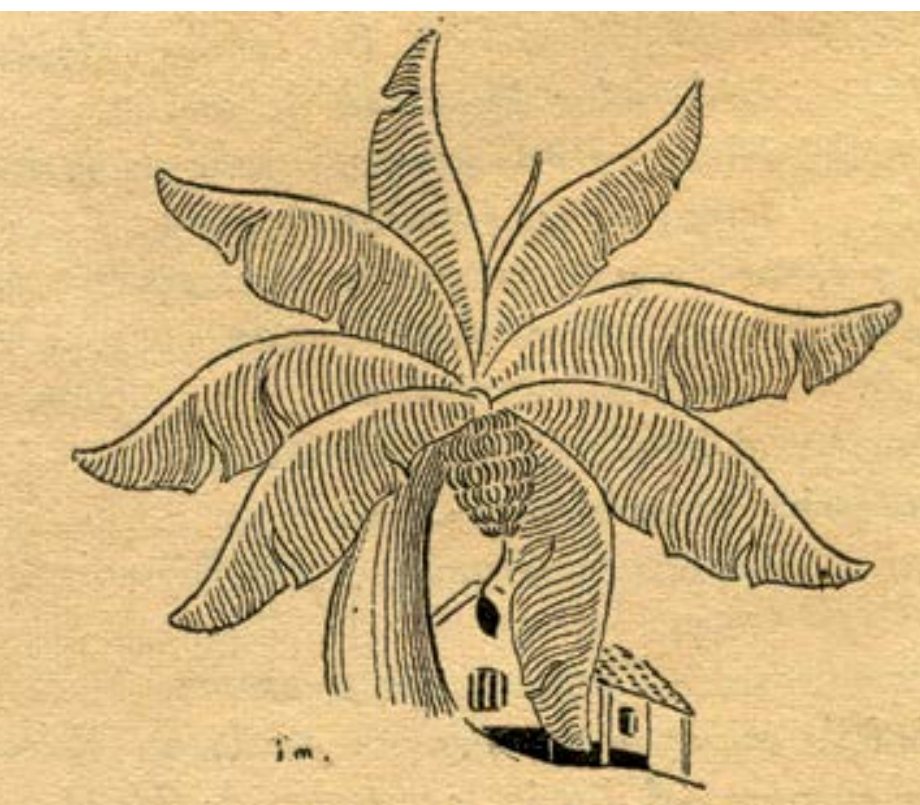

(Dibujo de Sánchez). llevada a su máxima expresión por el indio Sánchez. origen indígena de Curriravá, artista origen indigena de Currirava, artista también de la talla directa con veneración a la forma y naturaleza intrínseca del material por tallar. Para la escultura, gustó de usar la madera o la piedra, interpretaba piezas nobles y las trabajaba decididamente y siguiendo las sugerencias del material y su forma; conjugaba forma y sentimiento, siones, cortes precisos y redondeados, siempre en búsqueda de la belleza y el alma inherente a sus imágenes. Juan Manuel Sánchez buscó inspiración en
Pues el maestro Juan Manuel era de ma; conjugaba forma y sentimiento sus raíces, en su tierra natal, en los animales autóctonos y en el llamado arte precolombino; en su tiempo fue reconocido precisamente porque, con su trabajo de estética indigenista, revaloró las máximas cualidades y madurez estetica de la creación propia o de espíritu originario, defendiéndola frente a la influencia del patrón de la academia clásica europea. Juan Manuel defendía la creatividad del arte autoctono pues consideraba a la imaginación y al espiritu portadores de la herencia genética de la Historia.

De manera que tenemos presentes en Clotilde, Armando, Yolanda, Rogelio, Johnny, Hugo, Rafael, Juanita, Claustina y tantos más, a orgullosos herederos de nuestros primeros, auténticos y originarios ancestros creadores plásticos, de nueslo priveridad cultura La veta continua, la tradicion no ha muerto, la presencia de Atlántica de Talamanca y en otros grupos del país.

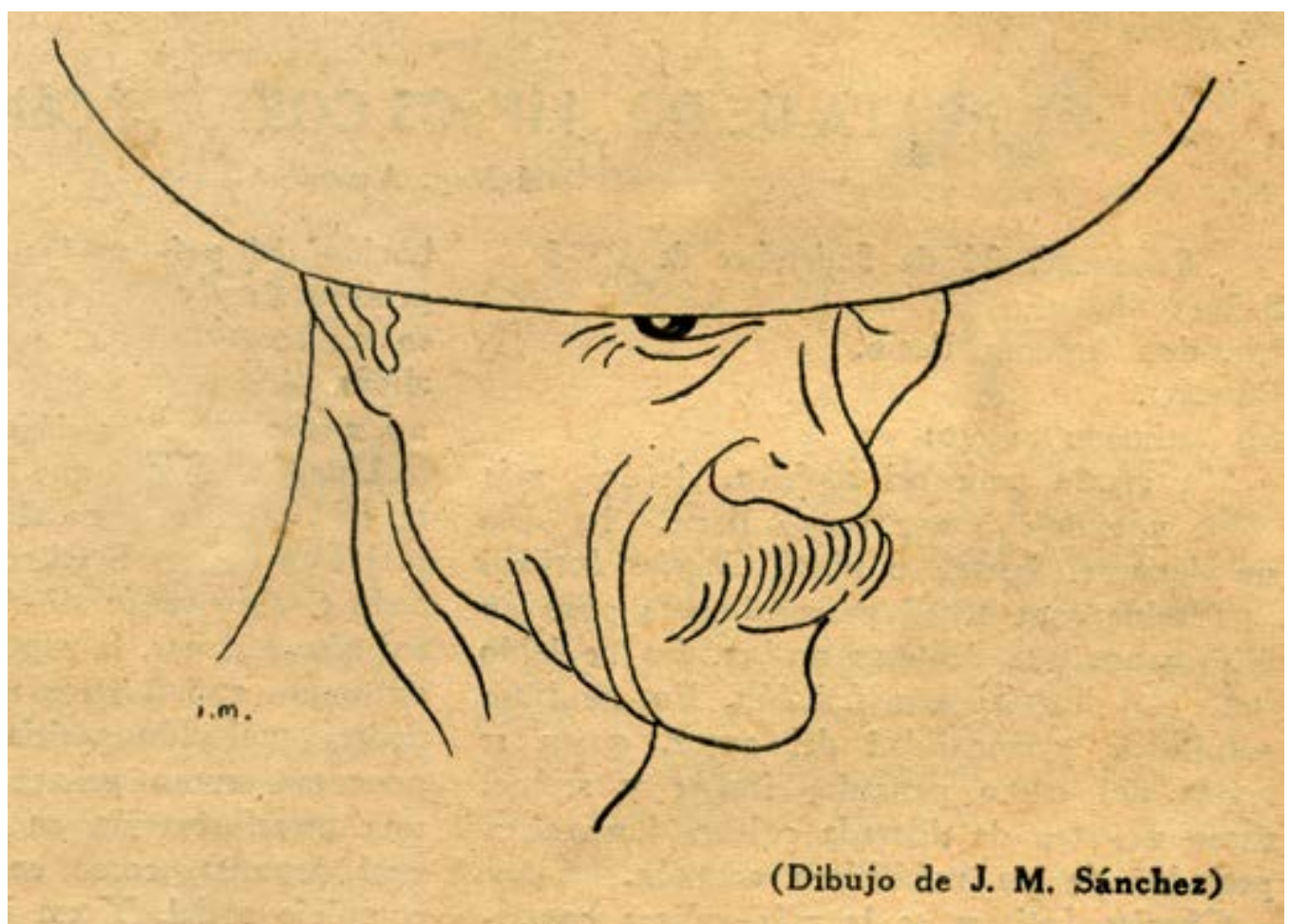

Foto 12. Juan Manuel Sínchez Sin titullo Dibujo a tinta 
